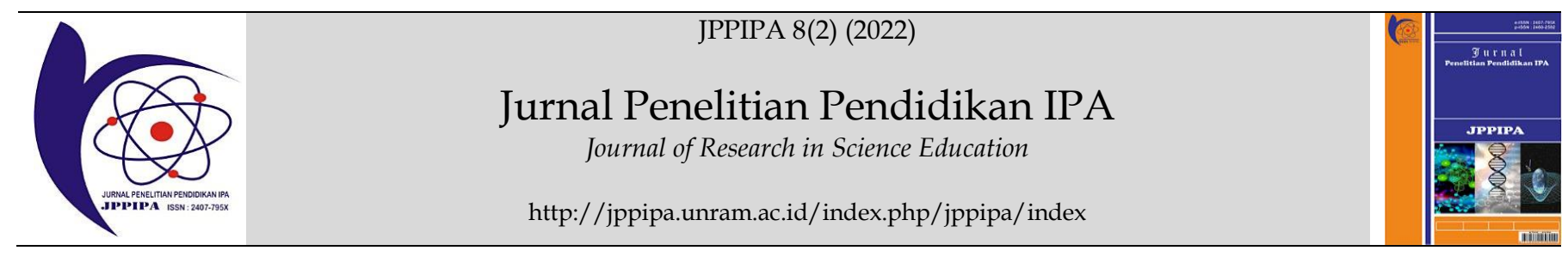

\title{
Characterization and Chemical Composition Analysis of Tea Tree (Meleuca alternifolia) Leaf Hydrosols Growing on Lombok Island
}

\author{
Baiq Riyankati ${ }^{1}$, Surya Hadi ${ }^{1}$, Sri Seno Handayani ${ }^{1 *}$ \\ ${ }^{1}$ Chemical Study Program, Faculty of Mathematics and Natural Sciences, University of Mataram, Indonesia.
}

DOI: $10.29303 /$ ippipa.v8i1.1239

\section{Article Info}

Received: November 30, 2021

Revised: January 3, 2022

Accepted: January 8, 2022

Published: January 31, 2022

\begin{abstract}
Tea tree is an essential oil-producing plant from Australia which is also found growing in several parts of Indonesia, including the island of Lombok. So far, tea tree essential oil producers on the island of Lombok do not utilize by-products in the form of hydrosol (distilled water) produced in the process of making essential oils. In this study, the characterization and analysis of the chemical composition of the hydrosol of tea tree leaves growing on the island of Lombok was carried out. The characteristic aroma of hydrosol is similar to that of tea tree essential oil. The results of the GC-MS analysis also showed that the hydrosol of tea tree leaves also had similarities with the essential oil, composed of major compounds in the form of trans-caryophyllene (28.58\%), limonene (13.98\%) and terpinen-4-ol $(16.27 \%)$. Other compounds detected were -pinene $(4.14 \%)$, -pinene $(6.50 \%)$, -myrcene $(8.09 \%)$, -terpineol $(10.10 \%)$ and -terpinene $(5.77 \%)$.
\end{abstract}

Keywords: Hydrosol; Characterization; Chemical composition; Lombok Island; Tea tree

Citation: $\quad$ Riyankati, B. ., Hadi, S. ., \& Handayani, S. S. . (2022). Characterization and Chemical Composition Analysis of Tea Tree (Meleuca alternifolia) Leaf Hydrosols Growing on Lombok Island. Jurnal Penelitian Pendidikan IPA, 8(1), 119123. https://doi.org/10.29303/jppipa.v8i1.1239

\section{Introduction}

Indonesia is an archipelagic country with abundant biodiversity, one of which is essential oilproducing plants. Indonesia is one of the largest essential oil producers in the world by producing around 40 types of essential oils (Ministry of Home Affairs, 2014). One type of essential oil that is currently being developed is tea tree (Meleuca alternifolia) essential oil. Tea tree is a plant from Australia which is also found growing or cultivated in several parts of Indonesia, including the island of Lombok.

The process of distillation of tea tree essential oil by the people of the island of Lombok generally uses the steam distillation method. Steam distillation method is a method that is widely chosen to extract essential oils from a plant because it can produce high yields of essential oils with good physical characteristics.
Through steam distillation of tea tree leaves, tea tree essential oil can be produced as the main product and a by-product in the form of distilled water or hydrosol. According to Rajeswara, (2012), hydrosol is a by-product of the distillation process in the form of a water emulsion solution that binds essential oils. During the distillation process, the water that is evaporated along with the essential oil will be separated after coming into contact with the cooling tube in the condensation process (Aćimović et al., 2020).

Until now, most of the essential oil industry still considers hydrosol as a by-product that has low economic value. In the essential oil production process, the hydrosol amount is much larger than the essential oil yield as the main product. Hydrosols that are not utilized and discharged into the environment can cause negative impacts such as increasing the value of chemical oxygen demand (Siregar, 2020). This is the reason for developing research on the content and

\footnotetext{
*Email: srihandayani@unram.ac.id
} 
benefits of essential oil hydrosols of various plants. According to Hung (2020) all hydrosols will contain dissolved essential oils. The solubility of the aromatic components in the hydrosol will depend on the content of the essential oil as the main product (Edris, 2009). Kahar (2021) reported that hydrosols can be used in cosmetics as toners, perfumes and spa baths. Another use of hydrosol is in traditional medicine as well as flavoring in beverages (D'Amato, 2018).

Several studies examining tea hydrosols have also been carried out, such as Li, et al. (2021) showed that tea tree hydrosols contain secondary metabolites similar to essential oils. The main components of hydrosol and tea tree essential oil have the same parent structure, but different degrees of oxidation. Terpinen4-ol, 2-endo-hydroxy-1,8-cineole and p-menth-3-ene1,2-diol are the main components in the essential oil and hydrosol of tea tree leaves which can act as antibacterial. Tea tree essential oil contains compounds from the monoterpenoid group that have the potential to be used as insect repellents (Cid-Pérez, 2019). Hammer, (2003) stated that the chemical compounds in tea tree essential oil have bioactivity as antibacterial, antiseptic, antifungal and insect repellent. The presence of these compounds indicates that tea tree leaf hydrosols can also be utilized in a wider variety of applications. In general, the type and chemical composition of plant metabolites, especially secondary metabolites, are strongly influenced by soil type, climate and the environment in which they grow. This can also be ascertained to occur in tea trees that grow on the island of Lombok. This article reports the chemical composition of metabolites, especially the secondary metabolites of tea tree leaf aerosol originating from Lombok Island and their potential utilization.

\section{Method}

\section{Sample Preparation}

In this study, tea tree leaves from North Lombok Regency were used which had been dried at room temperature for 5 days. The dried leaves obtained were chopped into small pieces and weighed. Then the water content was measured using equation 1.

$$
\text { Water Content }=\left(\left(b_{1}-b_{2}\right) / b_{1}\right) \times 100 \% .
$$

Description:

$b_{1}=$ weight of empty cup and weight of the sample before heating. $\mathrm{b}_{2}=$ final weight of the cup and sample after heating.
Production of Essential Oils and Hydrosols

$500 \mathrm{~g}$ of dried tea tree leaves were then steam distilled for 4 hours to obtain tea tree essential oil and its hydrosol as a by-product. The two are separated with the help of a separating funnel. The resulting essential oil was purified with anhydrous sodium sulfate followed by phytochemical tests and GC-MS analysis. After being separated from the essential oil, the hydrosol of tea tree leaves passed the stage of organoleptic testing (shape, color, and aroma) produced. Next, $100 \mathrm{~mL}$ of tea tree leaf hydrosol was extracted liquid-liquid with n-hexane (1:3). The nhexane hydrosol extract was then separated and concentrated using a rotary evaporator followed by phytochemical tests and chemical composition analysis using GC-MS. The results were compared with data on chemical compounds contained in tea tree essential oil.

\section{GC-MS Analysis}

The instrument used in this study was GC-MS QP2010 ULTRA SHIMADZU. The analysis was carried out using an injection temperature of $290^{\circ} \mathrm{C}$, a detector temperature of $300{ }^{\circ} \mathrm{C}$ and an initial column temperature of $40{ }^{\circ} \mathrm{C}$ with an increase of $80^{\circ} \mathrm{C}$ per minute to $280^{\circ} \mathrm{C}$. The carrier gas used is helium with a flow rate of $30 \mathrm{~mL} / \mathrm{min}$.

\section{Result and Discussion}

Steam distillation of $500 \mathrm{~g}$ of dry tea tree leaves using $1200 \mathrm{~mL}$ of water resulted in an essential oil yield of $1.626 \%$ and a hydrosol of $960 \mathrm{~mL}$ with a water content of $1.270 \%$. The resulting hydrosol in the form of distilled water is cloudy due to the presence of residual essential oils dispersed in it to form a homogeneous liquid. The hydrosol has a distinctive tea tree aroma although it is not as strong as the aroma of the essential oil. The resulting hydrosol can be seen in Figure 2 and the results of the phytochemical screening are shown in Table 2.

Table 1. Organoleptic test results for tea tree leaf hydrosols

\begin{tabular}{ll}
\hline Parameters Test & Results \\
\hline form & Homogeneous liquid \\
Color & cloudy \\
Aroma & Typical tea tree \\
\hline
\end{tabular}




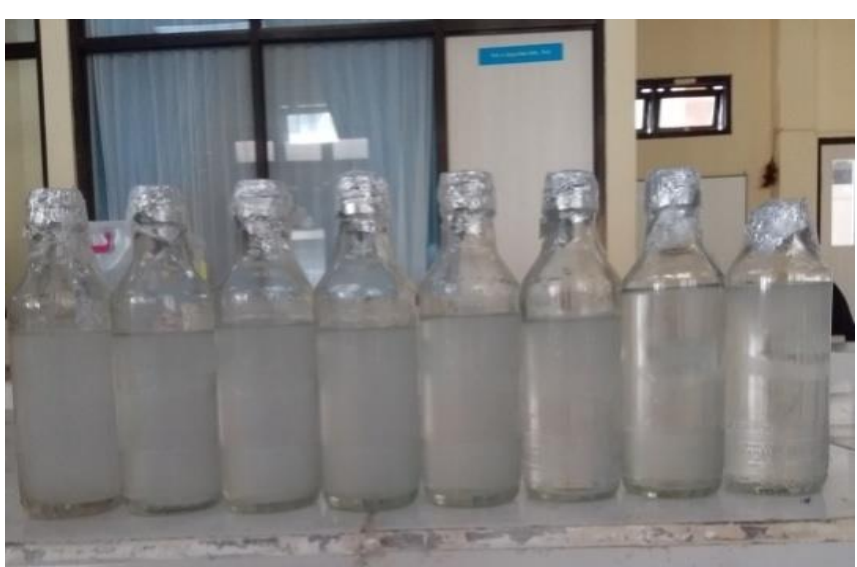

Figure 1. Tea tree leaf hydrosol

Table 2. Phytochemical Test results

\begin{tabular}{|c|c|c|c|c|}
\hline \multirow{2}{*}{$\begin{array}{l}\text { Phytochemi } \\
\text { cal Test }\end{array}$} & \multicolumn{2}{|c|}{ Tea Tree Essential Oil } & \multicolumn{2}{|c|}{$\begin{array}{l}\text { Hydrosol n-hexane } \\
\text { extract }\end{array}$} \\
\hline & Test results & Note. & Test results & Note. \\
\hline Saponin & $\begin{array}{l}\text { No foam } \\
\text { formed }\end{array}$ & - & $\begin{array}{l}\text { No foam } \\
\text { formed }\end{array}$ & - \\
\hline Flavonoid & $\begin{array}{l}\text { Clear solution } \\
\text { color }\end{array}$ & - & $\begin{array}{l}\text { Clear solution } \\
\text { color }\end{array}$ & - \\
\hline Terpenoid & $\begin{array}{l}\text { The color of } \\
\text { the solution } \\
\text { becomes } \\
\text { reddish } \\
\text { brown }\end{array}$ & + & $\begin{array}{l}\text { The color of } \\
\text { the solution } \\
\text { becomes } \\
\text { brownish red }\end{array}$ & + \\
\hline
\end{tabular}

Based on the data in Table 2. essential oils and hydrosols of tea tree leaves contain chemical compounds from the same group, namely terpenoids. Both also showed negative reactions to the saponin and flavonoid tests. This is different from the research conducted by Malathi, et al. (2020) which states that tea tree leaf essential oil contains secondary metabolites from the terpenoid and saponin groups. The main cause is most likely due to differences in extraction methods and geographical conditions where the plants are grown (Mann and Kaufman, 2012). Edris (2009) stated that the solubility of certain aromatic compounds from hydrosols is highly dependent on the chemical composition of the parent essential oil. Essential oil hydrosols containing secondary metabolites from different groups have diverse bioactivity. Eucalyptus globules hydrosol has the potential to be used as an insecticide on mealybugs because it contains secondary metabolites from the phenol and tannin groups (Sharma and Kaur, 2021). Research Cid-Pérez, et al. (2019) also showed that rosemary flower hydrosol containing saponins had antioxidant activity of 14.16 mg AAE/g.

The results of the phytochemical test in this study proved that the compounds that make up the essential oil and hydrosol of tea tree leaves are from the same group, although there are differences in the number and types of chemical compounds that make up the tea tree. GC-MS analysis of essential oils and tea tree leaf hydrosols yielded 10 peaks of compounds with different abundances, as shown in Table 3.

Table 3. Comparison of chemical compound composition

\begin{tabular}{|c|c|c|c|c|}
\hline \multirow[b]{2}{*}{$\begin{array}{l}\text { Chemical } \\
\text { Compound }\end{array}$} & \multicolumn{2}{|c|}{$\begin{array}{l}\text { Tea Tree Essential } \\
\text { Oil }\end{array}$} & \multicolumn{2}{|c|}{$\begin{array}{l}\text { Hydrosol n- } \\
\text { hexane extract }\end{array}$} \\
\hline & $\begin{array}{l}\text { Reten- } \\
\text { tion } \\
\text { Time }\end{array}$ & $\begin{array}{l}\text { Abun- } \\
\text { dance } \\
(\%)\end{array}$ & $\begin{array}{l}\text { Reten- } \\
\text { tion } \\
\text { Time }\end{array}$ & $\begin{array}{l}\text { Abun- } \\
\text { dance } \\
(\%)\end{array}$ \\
\hline a-pinene 6 & 6.725 & 6.280 & 6.724 & 4.140 \\
\hline$\beta$-pinene & 7.215 & 10.41 & 7.214 & 6.500 \\
\hline$\beta$-myrcene 1 & 7.361 & 14.23 & 7.362 & 8.090 \\
\hline Limonene 12 & 7.702 & 22.44 & 7.698 & 13.98 \\
\hline 8-terpinene ${ }^{10}$ & 7.943 & 9.680 & 7.942 & 5.770 \\
\hline Linalool $^{2}$ & 8.243 & 5.550 & - & - \\
\hline a-terpineol13 & 8.707 & 17.67 & & 10.100 \\
\hline $\begin{array}{l}\text { Monoacetyletandi } \\
\text { amine }^{4}\end{array}$ & 4.126 & 3.530 & - & - \\
\hline Alkohol diacetone 5 & 5.151 & 8.620 & - & - \\
\hline $\begin{array}{l}\text { 3-hydroxy- } \\
\text { Butanal }^{3}\end{array}$ & 7.560 & 1.700 & - & - \\
\hline Caren $^{8}$ & - & - & 7.598 & 2.180 \\
\hline Terpinen-4-ol11 & - & - & 8.764 & 16.27 \\
\hline $\begin{array}{l}\text { 1,8-epoxy-2- } \\
\text { menthanol }\end{array}$ & - & - & 8.978 & 4.380 \\
\hline $\begin{array}{l}\text { Trans- } \\
\text { caryophyllene }^{14}\end{array}$ & - & - & 10.048 & 28.580 \\
\hline
\end{tabular}
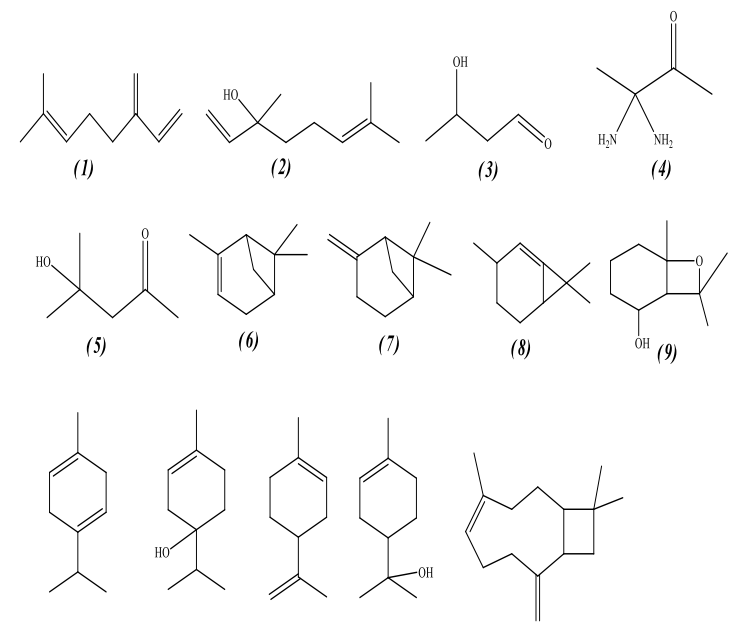

(11)

(12)

(13)

(14)

Figure 3. Structure of Chemical Compounds in Essential Oils and Hydrosol Tea Tree Leaves

The results of the GC-MS analysis showed that the essential oils and hydrosols of tea tree leaves contain some of the same chemical compounds and are from the monoterpenoid group. These compounds include -pinene, -pinene, -myrcene, -terpineol and terpinene. Most of the monoterpene compounds in hydrosols were detected in smaller amounts than in essential oils. The similarity of the chemical 
components that make up the essential oil and the hydrosol of tea tree leaves is caused by the dispersion of the remaining essential oil from the distillation in the hydrosol which can be physically proven by the distinctive aroma of tea tree and the resulting cloudy color. The major constituents of tea tree leaf hydrosols detected in this study were trans-caryophyllene (28.50\%) and limonene (13.98\%). Research Maia, et al., (2011) and Fajarini, (2015) mention that these compounds are commonly found in essential oils and have activity as insect repellents because of the aroma they produce. Monoterpene compounds such as pinene, -pinene, -myrcene, -terpineol and -terpinene in the hydrosol of tea tree leaves, apart from being able to act as insect repellants, also have antibacterial and antifungal bioactivity.

Table 4. Chemical composition of tea tree essential oil (ISO 4730: 2017).

\begin{tabular}{ll}
\hline Chemical Compound & Composition (\%) \\
\hline a-pinene & $1-4$ \\
Sabinene & $0-3.5$ \\
a-terpinene & $5-12$ \\
Limonene & $0.5-1.5$ \\
$\rho$-cymene & $0.5-8$ \\
1,8-cineole & $0-10$ \\
r-terpinene & $10-28$ \\
Terpinolene & $1.5-5$ \\
Terpinen-4-ol & $30-48$ \\
a-terpineol & $1.5-5$ \\
Aromadendrene & $0-3$ \\
Ledene & $0-3$ \\
d-candinene & $0-3$ \\
Globulol & $0-1$ \\
Viridiflorol & $0-1$ \\
\hline
\end{tabular}

In this study, the typical compound of tea tree plants in ISO 4730: 2017 in the form of terpinen-4-ol as contained in Table 4. was not found in tea tree essential oil but in hydrosol which is a by-product with an abundance of $16.27 \%$. This proves that the manufacture of essential oils through a simple process such as steam distillation produces a by-product in the form of hydrosol which is still very useful and can be further processed to maximize the potential of the chemical compounds contained in it. Terpinen-4-ol is currently widely used as an antibacterial in cosmetic products. terpinene and terpinen-4-ol compounds can inhibit the growth of Psudomonas aeruginosa bacteria (Cid-Pérez, 2019). The hydrosol of tea tree which contains terpinen4-ol, 2-endo-hydroxy-1,8-cineole and p-menth-3-ene1,2-diol as major compounds have good inhibitory power against Escherichia coli bacteria. minimum concentration of $1.25 \mathrm{mg} / \mathrm{mL}$ (Li, et al., 2021).

In addition, there are other compounds in tea tree leaf distilled water such as caren and 1,8-epoxy-2- menthanol which can be further utilized with more diverse bioactivity than tea tree essential oil. The large number of chemical compounds with various bioactivities makes hydrosols which were originally liquid waste from the volatile oil distillation process can be developed to be used as aromatherapy fluids, insect repellents and solvents in the process of making drugs and cosmetics.

\section{Conclusion}

Hydrosol, which is liquid waste from the steam distillation of tea tree leaves, physically still has a distinctive aroma like its essential oil. GC-MS analysis showed that there were similar chemical compositions in hydrosol and essential oil of tea tree leaves with major compounds in the form of trans-carryophyllene $(28.58 \%)$, limonene (13.98\%) and terpinen-4-ol (16.27\%). The chemical compounds detected were -pinene $(4.14 \%)$, -pinene $(6.50 \%)$, -myrcene $(8.09 \%)$, -terpineol $(10.10 \%)$ and -terpinene $(5.77 \%)$. Literature studies on the chemical content of aerosols show that there is great potential to be developed into chemical products with various bioactivities such as insect repellent, antibacterial, antifungal and antioxidant.

\section{References}

Aćimović, M., Tešević, V., Smiljanić, K., Cvetković, M., Stanković, J., Kiprovski, B., \& Sikora, V. (2020). Hydrolates: By-products of essential oil distillation: Chemical composition, biological activity and potential uses. Advanced Technologies, $9(2)$, $54-70$. https://doi.org/10.5937/savteh2002054a

Cid-Pérez, T. S., Ávila-Sosa, R., Ochoa-Velasco, C. E., Rivera-Chavira, B. E., \& Nevárez-Moorillón, G. V. (2019). Antioxidant and Antimicrobial Activity of Mexican Oregano (Poliomintha longiflora) Essential Oil, Hydrosol and Extracts from Waste Solid Residues. Plants (Basel, Switzerland), $\quad 8(1), \quad 22$. https://doi.org/10.3390/plants8010022.

D’Amato, S., Serio, A., López, C. C., \& Paparella, A. (2018). Hydrosols: Biological activity and potential as antimicrobials for food applications. Food Control, 86, 126-137. https://doi.org/https://doi.org/10.1016/j.foodc ont.2017.10.030

Edris, A. E. (2009). Identification and Absolute Quantification of the Major Water-Soluble Aroma Components Isolated from the Hydrosols of Some Aromatic Plants. Journal of Essential Oil Bearing Plants, 12(2), 155-161. 
https://doi.org/10.1080/0972060X.2009.1064370 5

Fajarini, D. A., \& Murrukmihadi, M. (2015). uji aktivitas repelan minyak atsiri daun kemangi (Ocimum Basilicum (L.) f. Citratum Back) terhadap nyamuk Aedes Aegypti dalam sediaan lotion dan uji sifat fisik lotion. Traditional Medicine Journal, 20(2), 91-97.

Hammer, K. A., Carson, C. F., \& Riley, T. V. (2003). Antifungal activity of the components of Melaleuca alternifolia (tea tree) oil. Journal of applied microbiology, 95(4), 853-860. https://doi.org/10.1046/j.13652672.2003.02059.x.

Hung, T., Trang, P., Viet, H., Lan, N., Ngan, L., \& Hieu, T. (2020). In vitro antimicrobial activity of hydrosol from Litsea cubeba (Lour.) Pers. against Helicobacter pylori and Candida albicans. Biomedical Research and Therapy, 7(6), 3819-3828. https://doi.org/10.15419/bmrat.v7i6.610

International Organisation for Standarisation (ISO) 4730. (2017). Oil of Melaleuca, Terpinen-4-Ol Type (Pohon teh Oil). International Organisation for Standardisation, Geneva, Switzerland.

Kahar, M.E., A Talip, B., Fauzi, N., Kamarulzaman, S. N., Zakaria, F., Muhammad, N., Mamat, T. N. A., \& Basri, H. (2021). Properties and potential of agarwood hydrosol as a drink: a review. Food Research, 5 , 29-35. https://doi.org/10.26656/fr.2017.5(3).382.

Li, X., Shen, D., Zang, Q., Qiu, Y., \& Yang, X. (2021). Chemical Components and Antimicrobial Activities of Tea Tree Hydrosol and Their Correlation with Tea Tree Oil. Natural Product Communications.

https://doi.org/10.1177/1934578X211038390

Maia, M. F., \& Moore, S. J. (2011). Plant-based insect repellents: a review of their efficacy, development and testing. Malaria Journal, 10(1), S11. https://doi.org/10.1186/1475-2875-10-S1S11.

Malathi, S., Lahari, S., Rajani, K., Sampagavi, M. \& Sushma, M. (2020). A Total Survey on Leaves of Malaleuca alternifolia (Pohon teh Oil), World Journal of Current Medical and Pharmaceutical Research, 2(4), 271-279. https://doi.org/10.37022/wjcmpr.vi.152

Mann, R., \& Kaufman, P. E. (2012). Natural Product Pesticides: Their Development, Delivery and Use Against Insect Vectors. Mini-Reviews in Organic Chemistry, 9, 185-202. https://doi.org/10.2174/157019312800604733.

Ministry of Home Affairs. (2014). Market Brief Minyak Atsiri 2014. Retrieved from: http://djpen.kemendag.go.id/membership/d ata/files/a409c-3119.pdf

Rajeswara, R. B. R. (2012). Hydrosols and water-soluble essential oils of aromatic plants: Future economic products. Indian Perfumer, 56, 29-33.

Sharma, A.D., \& Kaur, I. (2021). By-product hydrosol of Eucalyptus globulus essential oil distillation as source of botanical insecticides: wealth from waste. Notulae Scientia Biologicae, 13, 10854. https://doi.org/10.15835/nsb13110854

Siregar, I.P. (2020). Studi Pemanfaatan Water Aromatic/Hidrosol Sereh Wangi dalam Pembuatan Kosmetik Face Toner. Prosiding РTBB, 15(1), 1-8. Retrieved from: https://journal.uny.ac.id/index.php/ptbb/articl e/view/36469 